\title{
Enhancing resilience to coastal flooding from severe storms in the USA: international lessons
}

\author{
Darren M. Lumbroso ${ }^{1}$, Natalie R. Suckall ${ }^{2}$, Robert J. Nicholls ${ }^{3}$, and Kathleen D. White ${ }^{4}$ \\ ${ }^{1}$ HR Wallingford, Howbery Park, Wallingford, Oxfordshire OX10 8BA, UK \\ ${ }^{2}$ Geography and Environment, University of Southampton, University Road, Southampton SO17 1BJ, UK \\ ${ }^{3}$ Engineering and Environment, University of Southampton, University Road, Southampton SO17 1BJ, UK \\ ${ }^{4}$ US Army Corps of Engineers, Institute for Water Resources, National Capital Region (NCR), 7701 Telegraph Road \\ (Casey Building), Alexandria, Virginia 22315, USA
}

Correspondence to: Darren M. Lumbroso (d.lumbroso@hrwallingford.com)

Received: 8 November 2016 - Discussion started: 22 November 2016

Revised: 7 June 2017 - Accepted: 9 June 2017 - Published: 9 August 2017

\begin{abstract}
Recent events in the USA have highlighted a lack of resilience in the coastal population to coastal flooding, especially amongst disadvantaged and isolated communities. Some low-income countries, such as Cuba and Bangladesh, have made significant progress towards transformed societies that are more resilient to the impacts of cyclones and coastal flooding. To understand how this has come about, a systematic review of the peer-reviewed and grey literature related to resilience of communities to coastal flooding was undertaken in both countries. In both Cuba and Bangladesh the trust between national and local authorities, community leaders and civil society is high. As a consequence evacuation warnings are generally followed and communities are well prepared. As a result over the past 25 years in Bangladesh the number of deaths directly related to cyclones and coastal flooding has decreased, despite an increase of almost $50 \%$ in the number of people exposed to these hazards. In Cuba, over the course of eight hurricanes between 2003 and 2011, the normalized number of deaths related to cyclones and coastal floods was an order of magnitude less than in the USA. In low-income countries, warning systems and effective shelter/evacuation systems, combined with high levels of disaster risk-reduction education and social cohesion, coupled with trust between government authorities and vulnerable communities can help to increase resilience to coastal hazards and tropical cyclones. In the USA, transferable lessons include improving communication and the awareness of the risk posed by coastal surges, mainstreaming disaster risk reduction into the education system and building trusted com-
\end{abstract}

munity networks to help isolated and disadvantaged communities, and improve community resilience.

\section{Introduction}

People living in coastal areas face increasing storm-induced hazards including flooding caused by changing sea levels, high winds and waves, especially during tropical storms (Kron, 2013; Wong et al., 2014). As a result coastal populations are faced with property damages, economic losses, and in the worst cases, loss of life (Nicholls, 2006). Both highand low-income countries are affected by tropical storms. Typhoon Haiyan (2013) in the Philippines resulted in at least 6300 deaths and more than USD 2 billion in damages (Lagmay et al., 2015), whilst Hurricane Katrina (2005) in the USA resulted in some 1800 deaths and USD 50 billion in losses (Kates et al., 2006).

Over the past 60 years, the disparity between the rich and poor has increased in the USA, and the poorest people, who tend to live in communities on the fringes of urban areas, in inner cities and remote rural areas, have become increasing physically and socially isolated (Morrow, 1999; Reardon, 2011). These isolated households often have limited social networks to call upon in times of emergency, making them more vulnerable and less resilient to natural hazards than better-connected households (Morrow, 1999; Srinivasan et al., 2003; Macardle, 2014). 
Currently, almost $3 \%$ of the USA's population lives in areas directly subject to a $1 \%$ annual exceedance probability coastal flood (Crowell et al., 2013). Over the past decade, coastal flooding resulting from extreme events, such as hurricanes Katrina, Rita and Sandy, has highlighted a lack of resilience in the coastal population of the USA, especially amongst disadvantaged and isolated communities. The 13state region of the US south-east is particularly vulnerable in that it contains approximately $80 \%$ of all the US counties that experience persistent poverty ${ }^{1}$ (Thompson and Gaviria, 2004). There has also been an increase in vulnerability as a result of more people in hurricane-affected coastal counties living in mobile homes. Between 1970 and 2000, the percentage of the total population living in mobile homes in coastal counties increased from 8.4 to $23.2 \%$ (Cutter et al., 2007). Coastal flooding may be further exacerbated by climate change, including changing sea levels. Of $52 \mathrm{com}-$ munities located on the USA's eastern and Gulf coasts, twothirds are likely to experience a tripling or more in the number of annual high-tide floods by 2030 (Spanger-Siegfried et al., 2014). This is a particular problem in the Gulf region of the USA, where over $99 \%$ of the most socially vulnerable people $^{2}$ live in areas likely to be subject to coastal flooding, compared to only $8 \%$ of the least socially vulnerable (Martinich et al., 2013).

The future impact of climate change on coastal flooding and the combination of growing coastal populations and rising sea levels create a major hazard that requires urgent adaptation. The impacts of coastal flooding can be large, and some measures that reduce losses can be highly cost effective. In the USA, one study of spending on relief and recovery found that the federal government spent USD 136 billion on disaster relief between 2011 and 2013; the equivalent of nearly USD 400 per household per year (Weiss and Weidman, 2013). There is a need to establish new and improved policies, strategies and measures capable of adapting to an uncertain future that encompass integrated portfolios of structural and non-structural measures. In this paper structural measures are considered to involve any physical infrastructure to reduce or avoid possible impacts of floods (e.g. flood defences and barriers). Non-structural measures are those that do not require infrastructure, such as policies and laws, improved warnings, public awareness raising, training and education as well as flood proofing or elevating buildings, relocation and floodplain management. For an integrated portfolio of measures to be successful, there is a need to increase the resilience of communities, especially disadvantaged ones.

\footnotetext{
${ }^{1}$ This is a county in the USA where $20 \%$ or more of its population has lived in poverty over the past 30 years based on US census data

${ }^{2}$ Where social vulnerability is defined by the Social Vulnerability Index (SVI), originally formulated by Cutter et al. (2003)
}

To examine how the USA may be able to increase its resilience to coastal floods, we have considered experience from low-income countries. Here, governments face significant financial constraints in providing infrastructure to protect populations from severe storms. Despite financial challenges, some low-income countries have made significant progress in reducing deaths, as well as ensuring that people are able to maintain their livelihoods following events, by focusing on increasing resilience. These approaches do not depend on hard and soft infrastructure alone but also include interventions that draw on and enhance social capital ${ }^{3}$ and self-sufficiency of the community (Adger, 2003; Norris et al., 2008; Cash et al., 2013). These successes present an opportunity for learning on how to increase the resilience of their own disadvantaged communities to coastal flooding.

In this paper, we aim to analyse how the resilience of communities has been increased in Bangladesh and Cuba, including this social dimension, and consider the lessons for the USA. These countries were investigated because they both experience severe storms that can significantly affect large and vulnerable coastal populations, and both countries have made significant progress towards transformed societies that are more resilient to the impacts of cyclones and coastal flooding. To understand the transferable lessons from Bangladesh and Cuba, we conducted a systematic review of the literature on resilience of communities to coastal storms and surges.

The first part of the paper details the definition of resilience used in this paper and provides background on American communities' resilience to coastal flooding. The second part of the paper provides background on the case study countries before introducing the systematic review method used in this research. The measures that have been used to increase communities' resilience to coastal flooding and cyclones in Bangladesh and Cuba are then discussed, together with lessons that can be drawn from these for the USA.

\section{Resilience: absorbing, adapting and transforming}

\subsection{Conceptual background}

In the context of this paper, we use the United States Army Corps of Engineers' (USACE) definition of resilience, which is "the ability to anticipate, prepare for, and adapt to changing conditions and withstand, respond to, and recover rapidly from disruptions" (Schultz and Smith, 2016). In our conceptualization of resilience, we recognize the importance of the political, social and cultural relationships that underpin society and its capacity to respond to stress. Within that context, we consider Béné et al.'s (2012) concept of resilience com-

\footnotetext{
${ }^{3}$ Social capital can be features of social organization such as networks, norms, and social trust that facilitate coordination and cooperation for mutual benefit (Putnam, 1995)
} 


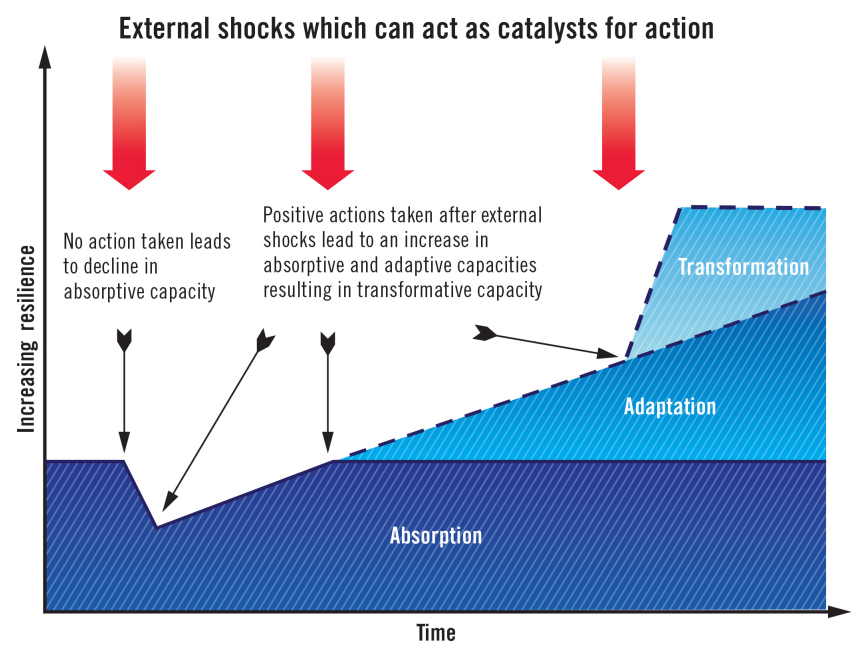

Figure 1. An illustration of the relationship between absorption, adaptation, transformation and resilience over time.

prising three components, (1) absorption, (2) adaptation and (3) transformation, as follows:

1. Absorption is concerned with resisting the initial impacts of a shock. It relies on strategies to cope with the shock rather than instigating a significant change to reduce or avoid future shocks.

2. Adaptation refers to the reactive or anticipatory responses that reduce risk and enable households, communities or governments to continue to function during and after the shock, but without significant structural changes.

3. Transformation refers to changes that alter societal functioning to a new and fundamentally improved state (Walker et al., 2004; Folke et al., 2010). This may occur as the cumulative effect of sustained incremental adaptations (Park et al., 2012; Kates et al., 2012) or it can also take place more rapidly. Transformation may be reactive or anticipated. Where transformation occurs it demands a substantial change away from the status quo (Lonsdale et al., 2015).

All three of these components are generally present where communities have increased their resilience to natural hazards. Figure 1 illustrates the relationship between absorption, adaptation, transformation and resilience. External shocks such as floods which severely impact communities can lead to changes in policies and the implementation of measures that can help to increase communities' resilience to future events (Birkland, 2006).

\section{Resilience of communities in the USA to coastal flooding}

Over the past decade or so, coastal flooding from severe storms in the USA, most especially hurricanes Katrina and Sandy, has disproportionately affected disadvantaged communities including low-income home owners (Elliott and Pais, 2006), the inner-city poor (Cutter et al., 2006), older people (Brunkard et al., 2008) and minorities (Dyson, 2006). Katrina saw a significant loss of life, and the mortality rate was up to four times higher among non-whites compared to whites (Brunkard et al., 2008). Furthermore, whilst around $80 \%$ of the population left New Orleans in advance of Hurricane Katrina and escaped the risk of death during the storm, the socially disadvantaged, who lacked access to transport, money for fuel or alternative accommodation, were forced to stay in their homes or evacuate locally (Brodie et al., 2006). In Hurricane Sandy, the majority of the people who died were older residents (over 60) (CDC, 2013). Of the 20 people who drowned in their homes in New York, a major reason for not evacuating was an inability to leave owing to a lack of transportation (CDC, 2013).

With respect to economic status, disadvantaged groups are also disproportionately affected. For example, 12 months after Katrina, the unemployment rate amongst non-returnees to an affected state was $35.7 \%$, compared to a national average of $3.7 \%$ (Zissimopoulos and Karoly, 2010). Non-returnees were more likely to be young, unmarried, black women who did not have a university degree. In terms of property loss, $53 \%$ of black residents reported they lost everything, compared with only $19 \%$ of white residents (Lavelle, 2006). Similarly, following Sandy the majority of those who registered for Federal Emergency Management Agency (FEMA) assistance following New York City's storm surge were renters with low incomes (FEMA, 2010).

Following Hurricane Sandy, a range of coastal riskreduction measures were considered for New York including a large surge barrier, although more limited measures were initially selected (USACE, 2015). For example, around lower Manhattan multifunctional flood defences and measures to flood-proof buildings are being implemented. However, isolated and socially disadvantaged communities often remain vulnerable to coastal flooding. In some parts of the USA, there has not been an extreme coastal surge for many years, and as a result, awareness of the risk posed by coastal surges is low. For example, the state of Georgia has not experienced an extreme surge for more than 100 years. A recent survey found that less than one-quarter of Georgians living on the coast were very concerned about hurricanes and many people living in low-lying areas did not believe their homes could flood (USACE, 2014). The last significant hurricane landfall in Glynn County, Georgia was in 1898, which caused a $5 \mathrm{~m}$-high storm surge in the town of Brunswick. It has been estimated that should a similarly sized coastal surge occur in 


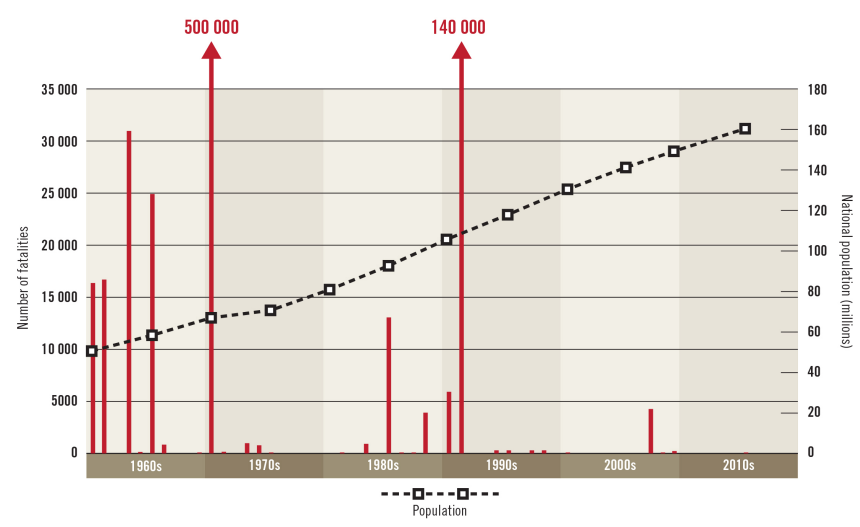

Figure 2. The number of fatalities caused by tropical cyclones and national population in Bangladesh between 1960 and 2015.

Brunswick today it would result in fatality rates of around $45 \%$ (Lumbroso et al., 2015).

\section{Case study countries: Bangladesh and Cuba}

\subsection{Bangladesh}

Bangladesh is located in South Asia, on the delta of the two largest rivers on the Indian subcontinent, the Ganges and Brahmaputra. It covers $144000 \mathrm{~km}^{2}$ (slightly larger than the state of New York), with large areas less than $1 \mathrm{~m}$ above high tide (Huq et al., 1995; Agrawala et al., 2003). Of the approximately 160 million population, around $50 \%$ live in the coastal floodplain (Neumann et al., 2015). Bangladesh is a low-income country; in a recent analysis based on gross domestic product (GDP) per capita adjusted for purchasing power parity, it ranked 140th out of 185 countries (Pasquali, 2015).

Bangladesh is especially vulnerable to cyclones because of its location at the triangular-shaped head of the Bay of Bengal, the low-lying nature of its coastal area, its high population density and the dearth of significant coastal flood defences (Haque et al., 2012). It is rated as one of the world's most vulnerable countries to tropical cyclones (UNDP, 2004). There has been at least 20 severe cyclonic storms making landfall since 1970 (Paul, 2009). In November 1970 Cyclone Bhola killed as many as 500000 people (Paul, 2010) and in April 1991 Cyclone Gorky, accompanied by a tidal surge of up to $10 \mathrm{~m}$, resulted in about 140000 deaths (Chowdhury et al., 1993). Figure 2 shows the number of cyclone-related fatalities and population growth between 1960 and 2015.

\subsection{Cuba}

Cuba is a large Caribbean island nation. The 2012 census estimated Cuba's population to be 11.1 million, with a population density of 100.7 inhabitants $\mathrm{km}^{-2}$. Based on GDP per capita adjusted for purchasing power parity it is ranked 136th in the world (CIA, 2016) and is a low-income country. Hurricanes are the major natural hazard to affect Cuba. In 1926 a hurricane caused 600 deaths and in November 1932 a hurricane with wind speeds of almost $250 \mathrm{~km} \mathrm{~h}^{-1}$ caused a storm surge $6 \mathrm{~m}$ high and led to some 3000 deaths (Cubahurricanes.org, 2016). In 1963 Hurricane Flora resulted in some 1500 deaths (Pichler and Striessnig, 2013). The island is affected by the same hurricane systems that impact the eastern and Gulf coasts of the USA. However, over the course of eight hurricanes between 2003 and 2011, there were 44.73 deaths per million people at risk in the USA and only 2.43 deaths per million people at risk in Cuba (Newhouse, 2011).

\section{Systematic review method}

To develop an understanding of how the resilience of communities to coastal flooding and tropical cyclones in Bangladesh and Cuba has increased, we conducted a systematic review of the peer-reviewed and grey literature in both countries. With origins in the health science literature, systematic reviews are increasingly used to explore climate change adaptation (Berrang-Ford et al., 2011; AntwiAgyei et al., 2014; Porter et al., 2014). An explicit procedure is followed whereby documents that focus on a specific issue are analysed according to clearly formulated questions. In this review, we aimed to establish what measures have contributed towards increasing community resilience in Bangladesh and Cuba.

We follow a realist approach (see Pawson et al., 2005). This approach is more suited to understanding why and how complex social interventions work (or fail) rather than stating the outcome of, for example, medical interventions as in the case in Cochrane-style reviews, which often aim to quantify the effectiveness of a discrete intervention (Pawson and Tilley, 2004). In using such an approach, we focus on a deep qualitative understanding rather than a broad understanding of the problem. As such, we apply a strict inclusion and exclusion criteria, shown in Table 1, and fewer documents are considered than in other review approaches (Thompson et al., 2010).

We followed a two-step process in retrieving articles for potential review. Firstly, to identify articles of interest in the peer-reviewed literature, we conducted a keyword search in the ISI Web of Science. We used the terms "Climat*", "Adapt*", "Cyclon*", "Hurricane", "Flood*", "Resili*" or "Storm-surge" coupled with the term "Bangladesh" or "Cuba". Each abstract was reviewed and articles that were irrelevant were excluded based on the criteria outlined in Table 1 . Second, to identify articles in the grey literature, including non-governmental organization (NGO) documents, working papers and university theses, we used a snowballing method whereby advice on relevant publications was sought from key experts (Hagen-Zanker and Mallett, 2013). We rec- 
Table 1. Inclusion and exclusion criteria.

\begin{tabular}{|c|c|}
\hline Include & Exclude \\
\hline Intervention contributes to resilience & Development action only \\
\hline Intervention focuses on fatalities, health or livelihoods & Coastal flooding is not addressed \\
\hline $\begin{array}{l}\text { Intervention is in response to or anticipation } \\
\text { of coastal flooding from a severe storm }\end{array}$ & Focus is on natural system \\
\hline \multirow{3}{*}{$\begin{array}{l}\text { Observable intervention has been implemented } \\
\text { Articles are post-1991 (to include analysis of the } \\
\text { period after Cyclone Gorky, Bangladesh) }\end{array}$} & Material is not in English \\
\hline & Geographic area is incorrect \\
\hline & $\begin{array}{l}\text { Articles are theoretical or speculative } \\
\text { (i.e. do not include observable information) }\end{array}$ \\
\hline
\end{tabular}

ognize that this method may create a researcher bias because experts may not be objective; however, we also recognize that this method can highlight important information not represented in peer-reviewed journal articles (Hagen-Zanker and Mallett, 2013).

Overall, we excluded 1518 peer-reviewed documents from the review for the reasons presented in Table 2 . We reviewed 127 documents, shown in Table 2. This comprised 76 papers on Bangladesh: 25 peer-reviewed and 51 grey literature documents. From Cuba, we review 6 peer-reviewed and 45 grey literature documents. In the following section, we present results of our analysis.

\section{Results of the systematic review}

\subsection{Increasing communities' resilience to coastal flooding and cyclones in Bangladesh}

Over the past 55 years a number of coastal flood riskreduction measures have been implemented in Bangladesh. However, it is only in the past 25 years, since Cyclone Gorky, that these have had an impact in significantly reducing fatalities from cyclones and coastal flooding, despite an increase in the number of people exposed (see Fig. 2). This decrease in fatalities could arguably be a measure of the improvement in community resilience. Figure 3 shows the number of deaths caused by cyclones (Alam \& Dominey-Howes, 2015) and the risk-reduction measures that have been implemented that have increased the population's resilience to coastal floods. This section outlines the measures that have been employed over the past 55 years in Bangladesh and the impact that they have had on increasing community resilience.

\subsubsection{Improved preparedness and risk communication}

One of the keys to increasing community resilience and reducing loss of life is improving preparedness and the ability to take precautionary measures in response to threats. In 1965 the idea of a Cyclone Preparedness Programme (CPP) was introduced when the National Red Cross Society, now the Bangladesh Red Crescent Society, asked the International
Federation of the Red Cross and Crescent (IFRC) to support the establishment of an early warning system for the people living in the coastal belt of Bangladesh (Mathbor, 2007). Following independence, the CPP was officially formed in 1972 by the government of Bangladesh and the Bangladesh Red Crescent Society. The CPP's main vision is to reduce the risk and loss of human life and also to reduce the economic losses from the cyclones and tsunamis, mainly for the vulnerable communities living in the coastal belt of Bangladesh (Ha and Ahmed, 2015). CPP volunteers are trained in early warning dissemination, evacuation, search and rescue, first aid and relief operations. Basic disaster management and leadership training is also part of their capacity development process.

By the 2000 the CPP had 32000 volunteers, which rose to 50000 volunteers in 2015 (Ha and Ahmed, 2015). Volunteers serve without monetary benefit and are motivated by altruistic concerns for their family, friends and community, social responsibility, religious benefits, reputation and desire to gain community recognition (Amin, 2012). Past experience of cyclones in 1970, 1991 and 2007 has also been found to provide motivation for volunteers (Amin, 2012).

The CPP can now alert around eight million people across the whole coastal region, and can assist around four million of these to evacuate. The warning system uses Asia's largest radio network, linking the CPP's Dhaka headquarters with 143 radio stations. Radio warnings are then relayed by village-based volunteers using megaphones and hand operated sirens. The volunteers are also trained to rescue people and evacuate them to shelters, administer first aid, and assist in post-cyclone damage assessment and relief (Majumder, 2013).

Preparedness at a national government level has also improved. In 1985, the Bangladesh government introduced a Standing Orders for Cyclones document. This document outlines specific directives, duties and responsibilities regarding disaster management for all relevant public agencies, including regional and local administrators, relevant ministries, and the Bangladesh Army, Navy and Air Force (government of Bangladesh, 1999). These documents were updated in 2010 (WMO, 2011). 


\section{Major cyclones to hit Bangladesh causing more than 1000 deaths}

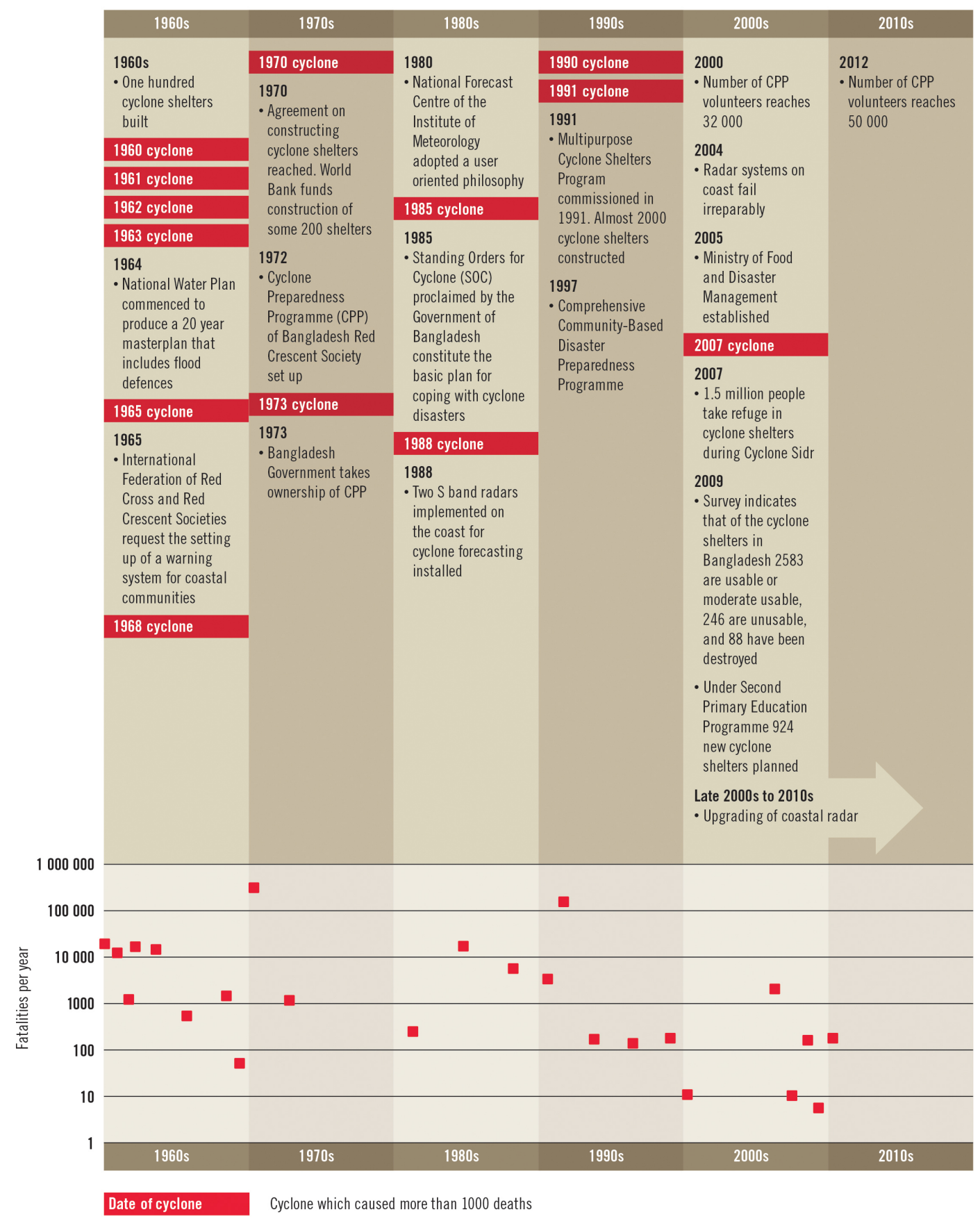

Figure 3. Timeline for Bangladesh showing the cyclones that have resulted in more than 1000 deaths, the number of fatalities and implemented risk-reduction measures.

In 1997, the Bangladesh Red Crescent Society launched a comprehensive community-based disaster preparedness programme with the aim of increasing the resilience of communities living in high-risk areas of disaster-prone districts (Bangladesh Red Crescent Society, 2008). This communitybased programme focuses particularly on women, as well as helping to increase community awareness concerning risks and how they can collectively act to reduce their exposure to hazards (Bangladesh Red Crescent Society, 2008). It also fosters community participation and unity to coordinate with the local government in fulfilling their responsibilities to save lives (Bangladesh Red Crescent Society, 2008). 
Table 2. Documents included/excluded in the review.

\begin{tabular}{|c|c|c|c|c|c|}
\hline Country & $\begin{array}{r}\text { Total peer-reviewed } \\
\text { documents }\end{array}$ & $\begin{array}{l}\text { Excluded (and on } \\
\text { what grounds) }\end{array}$ & & $\begin{array}{r}\text { Included in } \\
\text { review }\end{array}$ & $\begin{array}{l}\text { Total grey literature } \\
\text { included in review }\end{array}$ \\
\hline \multirow[t]{6}{*}{ Bangladesh } & 1405 & Development only & 413 & 25 & 51 \\
\hline & & Focus on natural systems & 298 & & \\
\hline & & Incorrect geographic scale & 88 & & \\
\hline & & Theoretical or speculative & 456 & & \\
\hline & & Paper not available & 68 & & \\
\hline & & Other & 364 & & \\
\hline \multirow[t]{6}{*}{ Cuba } & 138 & Development only & 10 & 6 & 45 \\
\hline & & Focus on natural systems & 67 & & \\
\hline & & Incorrect geographic scale & 16 & & \\
\hline & & Theoretical or speculative & 0 & & \\
\hline & & Paper not available & 6 & & \\
\hline & & Other & 32 & & \\
\hline
\end{tabular}

The programme assists communities with organizing themselves into "micro-groups" with 30 to 40 members in each, which act as the target group for household-level disaster risk-reduction interventions (Bangladesh Red Crescent Society, 2008). As part of the programme each community has volunteers who act as Community Disaster Response Teams and are trained to help vulnerable community members during extreme events.

There have also been efforts in Bangladesh to introduce disaster risk reduction into the education system. A learning kit for children on disaster risk reduction was developed and adapted to local contexts and language. The learning kit developed in 2005 was the first material of this type in the Bangla language aimed at helping children learn about disaster risk and take actions for risk reduction (UNISDR, 2007).

\subsubsection{Cyclone shelters}

The CPP's success has not only been as a result of improving awareness, preparedness and the dissemination of warnings, but also as a result of an improvement in the provision of cyclone shelters, together with the forecasting and planning for future cyclones. As early as the 1960s, some limited structural measures were being implemented to increase communities' resilience to coastal floods and tropical cyclones. These primarily took the form of purpose-built cyclone shelters, which were constructed in the 1960s for local vertical evacuation purposes only. Horizontal evacuation is not feasible owing to the large numbers of people, the large distances involved and the poor transport systems in Bangladesh. The shelters usually comprise concrete buildings raised on stilts or earth mounds so that they are raised above the extreme coastal surge level, which is often $4 \mathrm{~m}$ or more above the ground level. However, in the 1960s, there were only 100 cyclone shelters in the country (Rahman and Islam, 2011) hardly sufficient for the multimillion population of the coastal floodplain.
After Cyclone Bhola in 1970, which caused half a million deaths (Figs. 2 and 3), some 200 new cyclone shelters were constructed in the coastal areas of Bangladesh. Given that the average capacity of a shelter has been estimated to be around 1600 people (Dasgupta et al., 2010), these new structures did little to increase communities' resilience to coastal surges. Most of these original shelters are now unusable owing to structural issues or geomorphological changes in the coastal landscape (Jia, 2012).

After the 1991 cyclone, which resulted in 140000 fatalities, a Task Force on Cyclone Shelters was set up by the Planning Commission of Bangladesh. A Multipurpose Cyclone Shelter Programme was commissioned and the planning and design of new shelters were comprehensively studied by the government of Bangladesh, UNDP, the World Bank (Jia, 2012; Habib et al., 2012). This led to some 2000 multipurpose cyclone shelters being constructed. Most of these multipurpose cyclone shelters have been designed for use on a day-to-day basis as primary schools, typically with $250 \mathrm{stu}-$ dents (Jia, 2012). Primary-level education in coastal areas of Bangladesh is closely linked with cyclone shelters. The reasoning behind multipurpose shelters is that this allows for their continued use and upkeep in the periods between cyclones and also provides educational co-benefits by providing a location for primary schools in the coastal districts of the country.

Lessons learned over the past decades in the construction of cyclone shelters have further improved their designs. For example, shelters now include separate spaces for women, as the result of studies showing that women often did not use shelters because separate accommodation and washing facilities had not been provided for. In some cases, cyclone shelters were felt by women to be the domain of men, because when they were not being used as shelters they served as mosques or madrasahs ${ }^{4}$ (Hafiza and Neelormi, 2015). Many

\footnotetext{
${ }^{4}$ Institutions for the study of Islamic theology and religious law
} 
women believed that they were not sanctioned to enter such buildings (Hafiza and Neelormi, 2015).

Livestock plays a major role in Bangladeshis' lives, and their loss in a disaster can have a significant negative effect on income. In newer shelters, space for livestock is now standard in the designs. This feature helps communities to improved economic recovery following coastal flooding. However, there is still much work to be done, as it has been estimated that currently only around $2 \%$ of all cyclone shelters in Bangladesh have any kind of livestock facility (IRIN, 2012).

The construction of cyclone shelters is part of an ongoing programme. It has been estimated that by 2020 about 4760 new shelters are required in Bangladesh's 14 coastal districts where the CPP is operational and 7124 by the year 2025 (World Bank, 2014). The construction of these shelters will be phased, with priority based on the population density, coastal surge level, distance from existing shelters and the needs of the stakeholders (World Bank, 2014).

\subsubsection{Improved forecasting skill}

Together with the formation of the CPP, construction of cyclone shelters and the dissemination of warnings; improvements in the accuracy of cyclone forecasts has also played a part in increasing resilience. The Bangladesh Meteorological Department is the organization responsible for forecasting and warning for cyclones in Bangladesh (Miyan, 2005). In 1988 two S-band radars were implemented on the coast to improve cyclone forecasting, and in 2009 these were upgraded with Doppler radar systems. The Cyclone Warning Programme is managed by the Storm Warning Centre of Bangladesh Meteorological Department. It monitors the cyclonic disturbances in the Bay of Bengal and advises the government of Bangladesh on warnings that are issued in two stages. The first is an alert stage that provides a warning at least $36 \mathrm{~h}$ ahead of formation of cyclonic depression in the Bay of Bengal. The warning stage has three levels: "warning" $24 \mathrm{~h}$ before landfall, "danger" at least $18 \mathrm{~h}$ before landfall and "great danger" at least $10 \mathrm{~h}$ before landfall (WMO, 2011).

\subsubsection{Implications}

The construction of multipurpose shelters, together with improvements in cyclone forecasting, communication of early warnings, education, widespread mobilization of volunteers and community preparedness meant that the number of fatalities as a result of Cyclone Sidr were over 30 times lower than the cyclone of 1991, despite Cylone Sidr being of the same strength and the population at risk having increased by $37 \%$ (Paul, 2010). It is estimated that some 1.5 million people took refuge in cyclone shelters during Cyclone Sidr in 2007 (Ministry of Environment and Forests, 2009). Trust in governments and institutions such as the CPP during emergencies is generally very high. Survey data from two Bangladeshi islands show that around $98 \%$ of residents have trust in the early warning system (Paul and Rahman, 2006). More recently a survey of 200 households in coastal areas affected by Cyclone Sidr in 2007 and the less severe Cyclone Mahasen in 2013 found that $90.5 \%$ of the 200 respondents received warnings during Sidr, and this number increased to $96 \%$ during Mahasen (Roy and Kovordanyi, 2015; Roy, 2016). It also found that $83 \%$ of the respondents claimed the warnings to be understandable (Roy, 2016). This trust relates to the accuracy of the message (i.e. that a storm will follow) and confidence in local evacuation plans.

As Fig. 3 shows there have been a number of adaptation measures implemented in Bangladesh over the past 50 years that have increased resilience of communities in terms of increasing their absorptive, adaptive and transformative capacities. The first cyclone shelters constructed in the 1960s did little to increase communities' resilience owing to their limited number; deficiencies in their design; accuracy of the cyclone forecasts and the limited channels via which warnings were disseminated. It has generally been major events (i.e. Cyclones Bjola, Gorky and to a lesser degree Sidr) that have acted as catalysts for the implementation of adaptation measures to increase resilience. Figure 2 shows that despite the number of people in Bangladesh increasing by $250 \%$ over the past 55 years since 1991 the number of fatalities has decreased significantly. However, with sea-level rise and deltaic subsidence increasing flood potential and a population growth rate of $1.2 \%$, the process of transformation is ongoing and much remains to be done. The current cyclone shelters can only provide refuges for around $50 \%$ of the targeted population and are unevenly distributed in the areas at risk from cyclones and coastal flooding. Another issue is that there is often little funding for maintenance of shelters after they have been completed. If the goal of constructing some additional 7000 cyclone shelters over the next decade is not achieved it is possible that the increase resilience in Bangladesh may slow down.

\subsection{Increasing communities' resilience to coastal flooding and cyclones in Cuba}

Figure 4 shows a timeline of the hurricanes that have affected Cuba since 1960, the fatalities attributed to hurricanes each decade and the measures that have been implemented that have increased the population's resilience. This sections outlines the different measures that have increased communities' resilience to hurricanes over the past 50 years.

\subsubsection{Improved forecasting skill and credibility}

After Hurricane Flora, which resulted in some 1200 deaths, the Cuban government decided to create a civil defence structure and to develop the meteorological service that in 1963 only comprised two specialist meteorologists. Today Cuba's 


\section{Major hurricanes to hit Cuba}

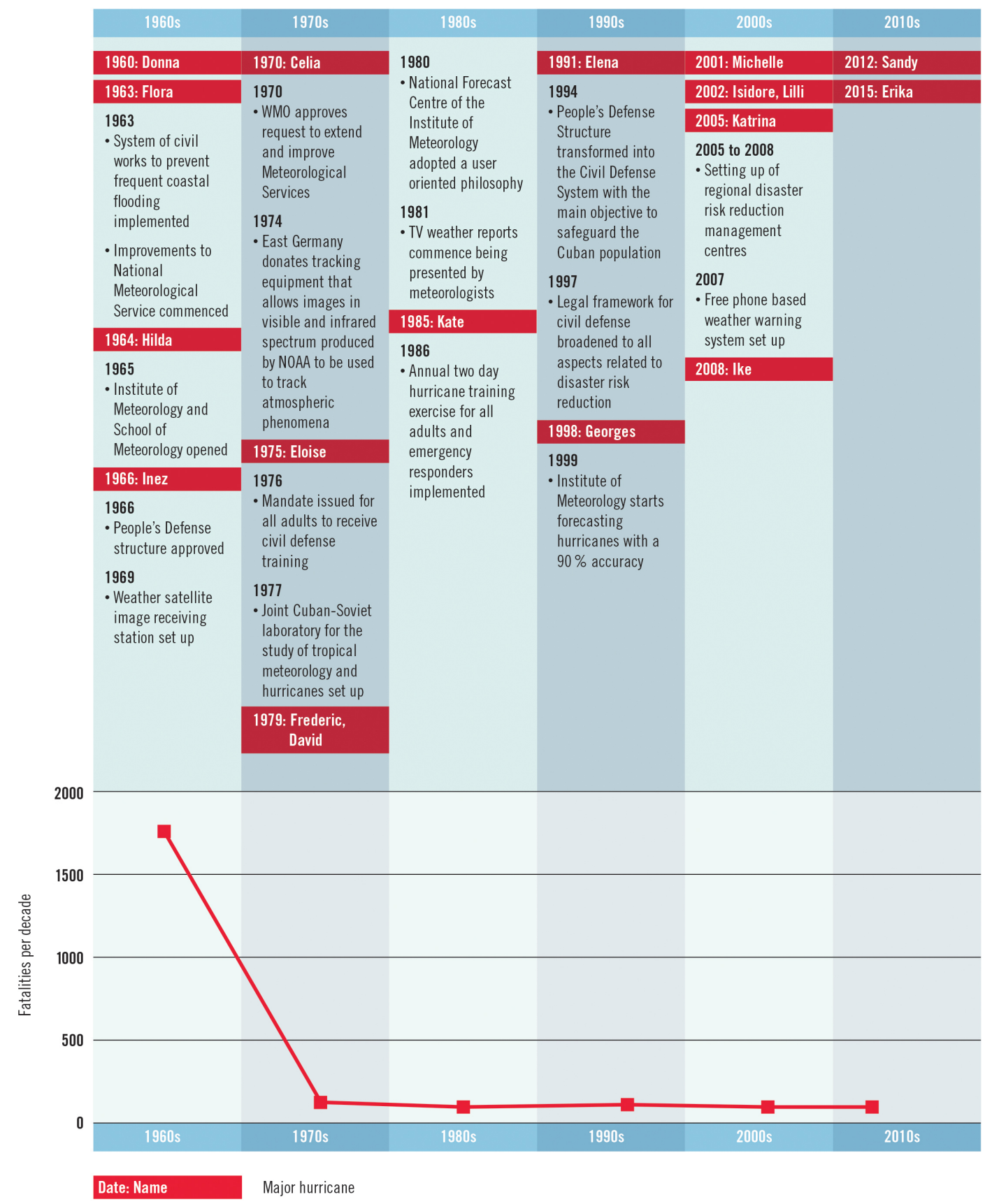

Figure 4. Timeline for Cuba showing major hurricanes, fatalities attributed to them each decade and implemented risk-reduction measures.

response to hurricanes is based on a highly professional and effective meteorological service and warning systems (Lezcano, 1995; Sims and Vogelmann, 2002), and on efforts that focus on mass education, awareness, preparedness and warnings that allow all members of the population to know how to respond when they receive advance notice of a tropical storm (Aguirre and Trainor, 2010).
The Cuban hurricane forecasting and advisory system is similar to the one used by the National Hurricane Center (NHC) in the USA. The Cuban Institute of Meteorology has eight radars, and operational access to satellite pictures (Naranjo Diaz, 2003; Rubeiera, 2012) and monitors the NHC as well. Operational forecasts are supported by Cuba's own hurricane prediction methods. Cuba is reported to be one of the few western hemisphere countries carrying out signifi- 


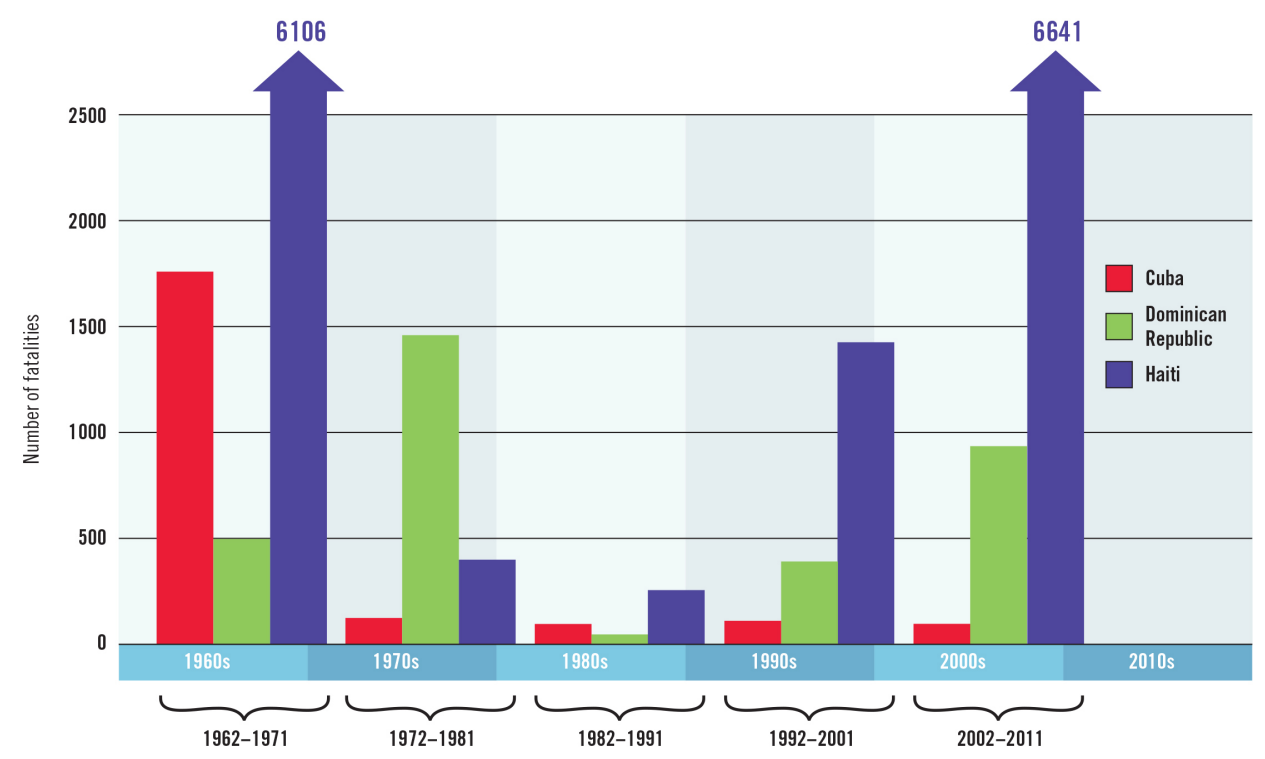

Figure 5. Total number of deaths per decade from weather-related natural hazards in Cuba, the Dominican Republic and Haiti between 1962 and 2011.

cant scientific research into hurricanes (Naranjo Diaz, 2003). The Cuban centre releases severe weather advisories every 12,6 or $3 \mathrm{~h}$ to correspond to the extent of the hazard (Naranjo Diaz, 2003)

The Institute of Meteorology in Cuba was not always a respected institution. In the 1970s and 1980s, meteorological forecasts in Cuba were jokingly referred to as coming from the "Instituto de Mentirologia" or the Institute for the Study of Lies (as opposed to the Institute for the Study of Weather ${ }^{5}$ ) (Schuett and Silkwood, 2008). The inability to forecast weather accurately led to low levels of credibility with the Cuban people. Ongoing improvements, which began in the 1980s, included investment in improved forecasting technological, enhanced communication (e.g. simplification of the language used in forecasts) and the replacement of TV broadcasters by trained meteorologists to ensure that weather reports were given accurately (Schuett and Silkwood, 2008). Dr. José Rubiera, the Chief Meteorologist of Cuba's Institute of Meteorology, has earned the trust and admiration of the people of Cuba for his knowledge and risk communication skills (Schuett and Silkwood, 2008). This increase in trust, coupled with good communication, means that radio broadcasts of hurricane warnings reach $97 \%$ and televised warnings reach $96 \%$ of the population (Thompson, 2007). This improved level of trust in Cuba has led to timely and coordinated evacuations, with the evacuation of the most vulnerable communities commencing $72 \mathrm{~h}$ in advance of the anticipated landfall of hurricanes.

\footnotetext{
${ }^{5}$ The Spanish word meterologia sounds similar to mentirologia which means "lies"
}

\subsubsection{Disaster response education}

In Cuba people are able to understand warning messages and know how to respond appropriately. Disaster preparedness and prevention are part of all school and university curricula (BRI and GRIPS, 2007; Moore et al., 2007; Garret et al., 2007). Every Cuban attends school and the education system plays a major role in creating awareness and preparedness. A wide variety of teaching methods are used. In addition, every May all adults undergo a mandatory disaster preparedness and response exercise (the Meteoro), during which evacuation procedures are practised. This simulation exercise allows government officials to identify vulnerable citizens (Keyser and Smith, 2009) and enables the evacuation of the most vulnerable communities $72 \mathrm{~h}$ in advance of a storm (Moore et al., 2009). All sectors of society take part from households to businesses to government (Thompson, 2007). In 2007 a new way to disseminate weather information and hurricane forecasts in Cuba commenced: the Weather Phone. The public has access to a free phone number that provides active advisories and warnings for dangerous weather phenomena (Rubeira, 2012).

The legal framework for present day disaster risk reduction in Cuba was initiated by the Cuban National Civil Defence Act 1976 which issued a mandate that every adult citizen had to undergo civil defence training. In 1997 the legal framework for civil defence was broadened to encompass all aspects related to disaster risk reduction (Thompson, 2007). The 1997 act also detailed the roles of ministries, social organizations, and all public bodies in the case of an emergency. This act also defined centralized decision-making with the president, head of civil defence and minister of the armed forces. The law also sets out decision-making by local au- 
(a) Bangladesh

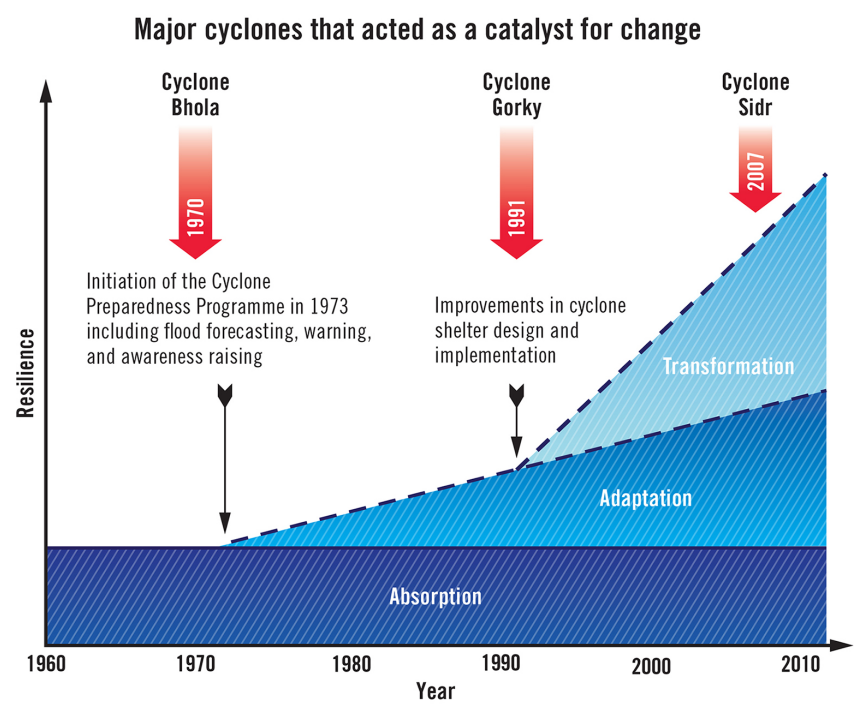

(b) Cuba

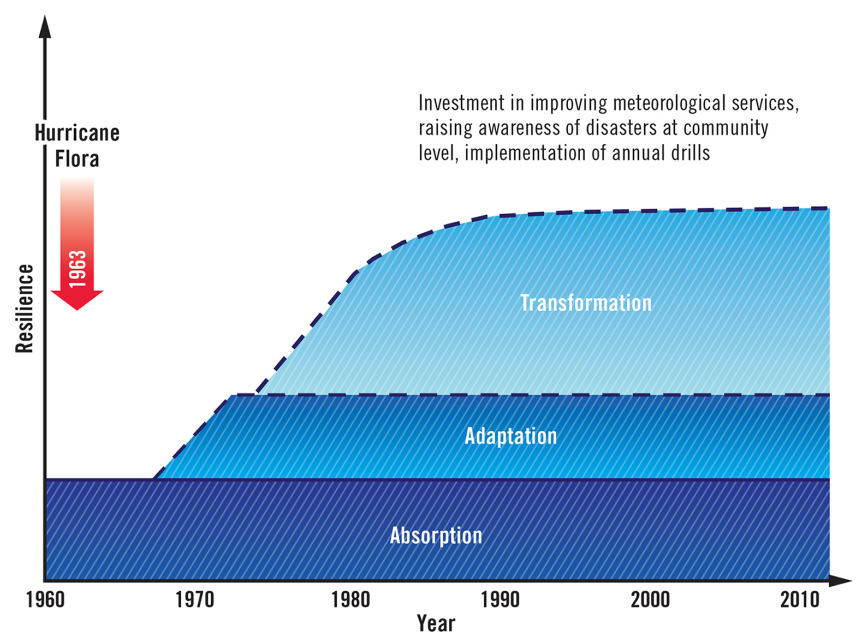

Figure 6. Conceptual diagram comparing and contrasting the development of communities' resilience to cyclones and coastal flooding in (a) Bangladesh and (b) Cuba since 1960.

thorities when required by the circumstances (Thompson, 2007).

Since 2000 Risk Reduction Management Centres (RRMC) have been implemented in Cuba. A total of 8 provincial and 84 municipal RRMCs, linked to 310 communities have been set up (UNDP, 2015). The objective of the RRMC model is to promote local-level decision-making using coordinated early warnings risk and vulnerability studies, together with community preparedness (UNDP, 2015). This model has generated widespread interest in the Caribbean. Commencing in 2009, the lessons learnt by Cuba and capacity building have been offered to other islands at risk in the Caribbean including the British Virgin Islands, the Dominican Republic, Guyana, Jamaica and Trinidad and Tobago (UNDP, 2015).

\subsubsection{Evacuation}

Mass evacuation is used in Cuba to get the population away from areas at risk from hurricanes (Pichler and Striessnig, 2013). Although evacuations are coordinated by the government they rely heavily on community assistance (Moore et al., 2009). Neighbourhood Committees for the Defence of the Revolution in Cuba provide information on the location and characteristics of vulnerable people to higher-level authorities during emergencies (Wisner, 2009). This shows that social networks are conduits for information flowing from the bottom up as well as from the top down. During an emergency, all available means of transport are mobilized by the local civil defence. Abandoned houses are sealed and people's possessions are taken to a safe place (Pichler and Striessnig, 2013). To prevent looting of the evacuated areas they are patrolled by the military. Community shelters are established in schools and community buildings at the beginning of the "alarm" stage, where they receive stocks of water, medicines and supplies. The different heads of government ministries cooperate closely. Each shelter has a director, deputy, physician, nurse, psychologist, veterinarian for pets and police and Red Cross representatives (Thompson, 2007; Pichler and Striessnig, 2013).

In Cuba, the disaster response is overseen by the Integrated Medical Emergency System (SIUM) (Mesa, 2008). Shelters are prepared $48 \mathrm{~h}$ before the storm is expected and are stocked with food, water, medical supplies and staffed by a doctor, nurse, police and Red Cross representative (Moore et al., 2009). Special attention is paid to planning medical care for vulnerable populations, such as pregnant women, the sick, small children and the disabled. Mental health counselling is also provided (Mesa, 2008). All doctors are assigned to their neighbourhoods and are able to check on the most vulnerable patients in their homes (Thompson and Gaviria, 2004). Furthermore, teams ensure that reserves of water, food and medications are already present in areas likely to be isolated in during an event (Mesa, 2008). The SIUM also has a role in hygiene/epidemiological surveillance. For example, following Hurricane Wilma (2005) public health teams (including hundreds of medical students) conducted house-to-house water quality tests (Mesa, 2008; Deybis Sánchez and Choonara, 2011). In the immediate recovery period, the Cuban government works with international NGOs to ensure safe drinking water and to repair water systems (Ortiz, 2010). In addition, the Ministry of Public Health issues chlorine tablets to purify water (Thompson and Gaviria, 2004). Finally, hospitals have clearly designated areas for patients during hurricanes with colour-coded directions. These remain marked all year round to avoid confusion during the event (Schuett and Silkwood, 2008). 


\subsubsection{Implications}

Hurricane Flora in 1963 acted as a catalyst for creating what is known in Cuba as a "culture of safety" (Pichler and Striessing, 2013). This culture of safety is based on the awareness of procedures to follow in the event of a hurricane: increasing communities' knowledge of stages of emergency warning, where to get information, how to secure houses and where to go for shelter. It also involved building up the basic trust of communities in the government's capacity and intention to protect them. The creation of a culture of safety did not happen overnight and involved a number of measures that have been implemented over the past 50 years. The effectiveness of the measures is illustrated by the number of fatalities in Cuba from weather-related hazards relative to its neighbours as shown in Fig. 5.

Community organization and a high degree of social capital have also played a key part in increasing resilience to hurricanes. Cubans are active in several types of social organizations, women organizations, youth organizations as well as particularly local disaster risk-reduction committees. These all act as forums within which to discuss disaster riskreduction. Cuban communities have consistently increased their social capital to help increase communities' resilience during times of rigorous economic scarcity. This raises the distinct possibility that concrete, practical measures to save lives might ultimately depend more on the intangibles of relationships, training and education than on high-cost procedures and resources (Thompson and Gaviria, 2004;. Pichler and Striessnig, 2013).

\section{Discussion}

In this section, we synthesize the findings of our analysis and present lessons that developed countries can learn from Bangladesh and Cuba about cost-effective investments to help improve community resilience to coastal flooding.

Figure 6 shows a conceptual diagram that compares and contrasts the development of resilience in Bangladesh and Cuba since 1960 in terms of absorption, adaptation and transformation components. A combination of measures have led to a transformation in the way communities function in the face of cyclones/hurricanes and coastal flooding. In Bangladesh this transformation has been the result of incremental increases in resilience over a number of years (Fig. 6a). There has been a shift from a relief centric approach to disaster risk reduction to a more holistic, multidisciplinary disaster risk-reduction approach. In Cuba, Hurricane Flora acted as "a wake-up call" to the government, which immediately implemented measures to improve its National Meteorological Service (Fig. 6b). Compared to Bangladesh, it could be argued that Cuban society transformed more rapidly, with fatalities from coastal flooding and cyclones having declined rapidly since 1963 (see Figs. 4 and 5). However, even 20 years after Hurricane Flora, the level of trust of people in the veracity of cyclone forecasts was low, meaning that there was still scope for resilience to increase considerably in the 1980s and to a lesser degree the 1990s. Improvements in the way that warning messages were communicated coupled with increases in the accuracy of forecasts helped to increase the public's trust in the technical experts responsible for delivering warnings.

Maintaining and enhancing trust comes across as a key component of enhancing flood resilience and this should be noted. This issue deserves further investigation in future studies in its own right. In both Cuba and Bangladesh the trust between the authorities (at national or sub-national levels), community leaders and civil society (i.e. the population at large) is high. As a consequence evacuation warnings are generally followed. In the USA, evacuation zones are delineated to effectively communicate warnings to the public. However, this is often problematic. The evacuation zones need to be communicated through an extensive public awareness campaign (FEMA, 2013). The turnover of emergency management staff, mainly as a result of low morale, is such that the evacuation zones are often forgotten (FEMA, 2013). In some cases evacuations can be politically driven rather than planned, and the evacuation zone terms are confused with floodplain terms (FEMA, 2013).

In the USA, there is no national-level decision process concerning evacuation: state and local governments have the authority to make their own decisions. Also, there is variable enforcement capacity related to evacuation. Variable adherence to these orders can lead to a failure to evacuate from high-risk areas and unnecessary evacuation from low-risk areas (Wallace et al., 2016). In Cuba, the local government has the capacity and authority to direct the evacuations based on the emergency plan which they and the local community have been responsible for formulating. In Bangladesh, the CPP volunteers work with communities to raise awareness, preparedness and to assist them with evacuations. Engaging members of American communities in the preparation of emergency plans at local level could help increase the trust, cooperation and level of self-help.

In the USA, horizontal evacuation is rightly stressed due to the potentially high level of fatalities that could occur during an extreme coastal flood event in many locations (Lumbroso et al., 2015; Jonkman, 2007). However, significant number of people do not comply with evacuation orders for various reasons. For example, around $20 \%$ of people remained in New Orleans for the landfall of Katrina. There are a range of possible responses to this issue. Following the Bangladesh experience, the provision of vertical evacuation to local, resilient, multipurpose shelters (e.g. schools, libraries, places of worship) warrants further investigation in a US context. The US Department of Homeland Security's STARTM Home Pilot Project is undertaking a pilot project to promote building design that recognizes best practices for building resilience to natural hazards. This pilot could be extended to this type 
of community facility/shelter. However, there are other approaches to address the issue of non-evacuation and these all need to be carefully considered with national, regional and local planners.

The resilience of communities to coastal surges and cyclones in Bangladesh and Cuba has also increased as a result of improvements in the way that warnings and other risk information related to these hazards are communicated. Research recently carried out in the USA showed that most emergency managers and broadcast meteorologists are concerned about the public's lack of comprehension of its vulnerability to storm surges (Morrow and Lazo, 2013a, b, c). In their opinion, many coastal residents lack sufficient knowledge about their vulnerability and do not comprehend the nature of storm surge (Morrow et al., 2014). Following Hurricane Katrina research indicated that emergency communication plans need to be improved for urban evacuation situations (Brodie et al., 2006). Researchers found that people in low-income areas need more explicit information on how to reach safety or evacuate if they have no vehicle, financial resources or place to stay outside the city, or if someone in their family is physically disabled (Brodie et al., 2006).

In the USA, researchers found that many people are "under-concerned" about the risk posed by coastal surges and that their evacuation intent are often overstated (FEMA, 2013). A post-Katrina behavioural survey found that most of the respondents in Alabama, Mississippi and Louisiana could not interpret a National Weather Service storm surge forecast correctly (Gladwin and Morrow, 2006). A survey completed just before Sandy indicated that people expected the primary hazard to be wind (Baker et al., 2012). However, most of the 67 deaths caused directly by Hurricane Sandy in the USA were due to drowning, primarily when the storm came ashore (CDC, 2012). Interviews conducted with 205 households in Beaufort County, North Carolina 1 month after Hurricane Irene in 2011 found that two-thirds of the population was unaware that any evacuation order had been issued and a similar percentage did not appreciate the risk posed by coastal flooding (Wallace et al., 2016).

One important way in which Cuba has increased its resilience to coastal flooding is incorporating disaster risk reduction into the curricula of the education system at a variety of levels. In the USA, FEMA and the Department of Education have been considering strategies to reach children and youth through disaster preparedness in schools and extracurricular activities (Johnson, 2011). However, disaster risk reduction is not required to be included in American schools' curricula at national, state and local level. Schools in the USA have the freedom to use and promote disaster preparedness using educational resources of their choosing or can develop their own (Johnson, 2011). More consistency in such education may be helpful.

During the past few years, FEMA has focused on developing teaching and learning resources for children, including the FEMA for Kids website (www.ready.gov/kids). This provides resources for students (aged between five and 18), parents and teachers including lesson plans, classroom activities and interactive games for children. The American Red Cross has developed a curriculum called "Masters of Disaster" to help teachers in the USA integrate important disaster safety instruction into their regular core subjects such as maths, science and social studies (UNISDR, 2007). This curriculum, aimed at children aged 5 to 14 and their families, focuses on disaster preparedness information and promotes behaviour change by providing people with the knowledge, skills and tools to effectively prepare for disasters (UNISDR, 2007). US states where the risk of coastal flooding is high could implement school disaster drills. For an initiative on disaster risk reduction in American schools to be sustainable it would require mainstreaming disaster risk reduction into the national school curricula. The challenge would be for all the relevant government departments to achieve consensus on a plan of action.

The socio-economic and political circumstances in both Bangladesh and Cuba differ from the USA; however, this does not mean that the lessons learnt cannot be applied in high-income countries. For example, Cuba has recently implemented a 3-year training programme for disaster riskreduction experts from the 15 countries that make up the Caribbean Community (CARICOM) (CubaSI, 2015). Many countries in the Caribbean which have distinctly different socio-political circumstances to Cuba have identified particular components of the Cuban disaster risk-reduction model that can complement and strengthen their existing risk-reduction procedures and structures (UNDP, 2015). Bangladesh has also shared lessons on community resilience via various worldwide community-based adaptation initiatives, and similar approaches are now being applied in Odisha, India. Further analysis of the effectiveness of these international exchanges of practice and experience would be instructive.

\section{Conclusions}

A high level of disaster risk-reduction education, social cohesion and solidarity coupled with trust between government authorities, community leaders and vulnerable communities can help to increase communities' resilience to coastal hazards and tropical cyclones. Both Bangladesh and Cuba have, over the past 40 years, made considerable improvements in how the risk posed by cyclones and coastal surges is communicated to isolated and vulnerable communities as well as improving warnings and evacuation/shelters. The trust at all levels in warnings and emergency management is high. However, this has not always been the case in either country. In the USA, trust in forecasts is high; however, individual and community response to warnings is variable for a number of reasons. One key element is improving the communication of evacuation orders, together with the actual risk posed to 
people by coastal flooding. Communities' resilience could be increased by improving communication and the awareness of the risk posed by coastal surges, mainstreaming disaster risk reduction into the education system and building trusted community networks to help isolated and disadvantaged communities improve resilience. To conclude policies that improve risk communication and disaster risk-reduction education can have multiplier effects that help to increase community resilience to natural hazards.

Data availability. This work was based on the peer and grey literature, all of which have been included as part of the references.

Competing interests. The authors declare that they have no conflict of interest.

Acknowledgements. We would like to acknowledge the support of the US Army Corps of Engineers Climate Preparedness and Resilience Community of Practice, who funded this research.

Edited by: Vassiliki Kotroni

Reviewed by: two anonymous referees

\section{References}

Adger, W. N.: Social capital, collective action, and adaptation to climate change, Econ. Geogr., 79, 387-404, 2003.

Agrawala, S., Ota, T., Ahmed, A. U., Smith, J., and van Aalst, M.: Development and climate change in Bangladesh: Focus on coastal flooding and the Sundarbans, OECD, Paris, 2003.

Aguirre, B. E. and Trainor, J. E.: Emergency management in Cuba: Disasters experienced, lessons learned, and recommendations for the future in comparative emergency management, in FEMA Comparative Emergency Management Book, available at: https://training.fema.gov/hiedu/aemrc/booksdownload/ compemmgmtbookproject/ (last access: 21 July 2017), 2010.

Alam, E. and Dominey-Howes, D.: A new catalogue of tropical cyclones of the northern Bay of Bengal and the distribution and effects of selected landfalling events in Bangladesh, Int. J. Climatol., 35, 801-835, 2015.

Amin, R.: Motivating volunteers: A case of the Cyclone Preparedness Programme, volunteers in Bangladesh, A dissertation for the degree of Masters in Disaster Management, BRAC University, Dhaka, Bangladesh, available at: http://dspace.bracu.ac. bd/bitstream/handle/10361/2724/md.ruhulamin.pdf?sequence=1 (last access: 21 July 2017), 2012.

Antwi-Agyei, P., Dougill, A. J., and Stringer, L. C.: Barriers to climate change adaptation: evidence from north-east Ghana in the context of a systematic literature review, Clim. Dev., 1-13, 2014.

Baker, E. J., Broad, K., Czajkowski, J., Meyer, R., and Orlove, B.: Risk perceptions and preparedness among mid-Atlantic residents in advance of Hurricane Sandy: Preliminary report. Risk Management and Decision Processes Center, The Wharton School,
University of Pennsylvania Working Paper 2012-18, 42 pp., 2012.

Bangladesh Red Crescent Society Building safer communities in South Asia: Case study Bangladesh, January 2008, available at: http://www.adpc.net/v2007/IKM/ONLINEDOCUMENTS/ downloads/2008/1_CaseStudyCBDMStructurel.pdf (last access: 29 June 2016), 2008.

Béné, C., Wood, R. G., Newsham, A., and Davies, M.: Resilience: new utopia or new tyranny? Reflection about the potentials and limits of the concept of resilience in relation to vulnerability reduction programmes, IDS Working Papers, 2012, 1-61, 2012.

Berrang-Ford, L., Ford, J. D., and Paterson, J.: Are we adapting to climate change? Global Environ. Chang., 21, 25-33, 2011.

Birkland, T. A.: Lessons of disaster, policy change after catastrophic events, Georgetown University press, Washington DC, USA ISBN 978-1-58901-121-2, 2006.

Brodie, M., Weltzien, E., Altman, D., Blendon, R. J., and Benson, J. M.: Experiences of Hurricane Katrina evacuees in Houston shelters: Implications for future planning, Am. J. Public Health, 96, 1402-1408, 2006.

Brunkard, J., Namulanda, G., and Ratard, R.: Hurricane Katrina deaths, Louisiana, 2005, Disaster Med. Public, 2, 215-223, 2008.

Building Research Institute (BRI) and the National Graduate Institute for Policy Studies (GRIPS): Disaster education, UNESCO, Paris, available at: http://www.preventionweb.net/files/ 3442_DisasterEducation.pdf (last access: 21 July 2017), 2007

Cash, R. A., Halder, S. R., Husain, M., Islam, M. S., Mallick, F. H., May, M. A., Rahman, M., and Rahman, M. A.: Reducing the health effect of natural hazards in Bangladesh, Lancet, 382, 2094-2103, 2013.

Centers for Disease Control and Prevention (CDC): Deaths associated with Hurricane Sandy-October-November 2012 Morbidity and mortality weekly report, 62, 393, 2013.

Central Intelligence Agency (CIA) The world fact book, available at: https://www.cia.gov/library/publications/the-world-factbook/ rankorder/2004rank.html (last access: 21 July 2017), 2016.

Chowdhury, A. M. R., Bhuyia, A. U., Choudhury, A. Y., and Sen, R.: The Bangladesh cyclone of 1991: Why so many people died, Disasters, 17, 291-304, 1993.

Crowell, M., Westcott, J., Phelps, S., Mahoney, T., Coulton, K., and Bellomo, D.: Estimating the United States population at risk from coastal flood-related hazards, in: Coastal Hazards, 151183, Springer Netherlands, 2013.

Cubahurricanes.org: Cuba hurricanes historic threats: Chronicle of hurricanes in Cuba, available at: http://www.cubahurricanes.org/ history-hurricanes-chronicles.php (last access: 21 July 2017), 2016.

CubaSI: Cuba trains Caribbean experts to address disaster risks, available at: http://www.cubasi.com/cuba/item/ 5700-cuba-trains-caribbean-experts-to-address-disaster-risks (last access: 21 July 2017), 2015.

Cutter, S. L., Boruff, B. J., and Shirley, W. L.: Social vulnerability to environmental hazards, Soc. Sci. Quarterly, 84, 242-261, https://doi.org/10.1111/1540-6237.840, 2003.

Cutter, S. L., Emrich, C. T., Mitchell, J. T., Boruff, B. J., Gall, M., Schmidtlein, M. C., Burton, C. G., and Melton, G.: The long road home: Race, class, and recovery from Hurricane Katrina, Environment: Science and Policy for Sustainable Development, 48, 8-20, 2006. 
Cutter, S. L., Johnson, L. A., Finch, C., and Berry, M.: The US hurricane coasts: increasingly vulnerable?, Environment: Science and Policy for Sustainable Development, 49, 8-21, 2007.

Dasgupta, S., Huq, M., Khan, Z. H., Ahmed, M. M. Z., Mukherjee, N., Khan, M. F., and Pandey, K.: Vulnerability of Bangladesh to cyclones in a changing climate: Potential damages and adaptation cost, World Bank Policy Research Working Paper 5280, 2010.

Deybis Sánchez, M. and Choonara, I.: Hurricanes and child health: Lessons from Cuba, Arch. Dis. Child., 96, 328-329, 2011.

Dyson, M. E.: Come hell or high water: Hurricane Katrina and the color of disaster, ISBN 0465017614, published by Basic Civitas Books, 2006.

Elliott, J. R. and Pais, J.: Race, class, and Hurricane Katrina: Social differences in human responses to disaster, Soc. Sci. Res., 35, 295-321, 2006.

Federal Emergency Management Agency (FEMA): Measuring the response to Hurricane Sandy, available at: http: //www.rebuildbydesign.org/research/resources/36-resources/ download/42_a1d0c6e83f027327d8461063f4ac58a6 (last access: 20 June 2016), 2010.

Federal Emergency Management Agency (FEMA): Readiness: Planning for the threat: Helping make protective action decisions when threatened by tropical cyclones, available at: http://www.nhc.noaa.gov/outreach/presentations/2013 09nhcL311_readiness.pdf (last access: 15 September 2016), 2013.

Folke, C., Carpenter, S. R., Walker, B., Scheffer, M., Chapin, T., and Rockström, J.: Resilience thinking: integrating resilience, adaptability and transformability, Ecol. Soc., 15, 2010.

Garrett, A. L., Grant, R., Madrid, P., Brito, A., Abramson, D., and Redlener, I.: Children and mega-disasters: Lessons learned in the new millennium, Adv. Pediatr., 54, 189-214, 2007.

Gladwin, H. and Morrow, B. H.: Coastal Louisiana post-Katrina evacuation planning survey: Final Report, Florida International University Institute for Public Opinion Research, Post-Katrina Behavioral Study Report, 44 pp., 2006.

Government of Bangladesh: Standing orders on disaster. Disaster Management Bureau, Dhaka, 1999.

Ha, H. and Ahmed A.: Bangladesh: Natural disaster risk management in Land and disaster management strategies in Asia, edited by: Ha, H., ISBN:978-81-322-1975-0, 83-98, 2015.

Habib, A., Shahidullah, M., and Ahmed, D.: The Bangladesh cyclone preparedness program. A vital component of the nation's multi-hazard early warning system, in: Institutional Partnerships in Multi-Hazard Early Warning Systems, 29-62, Springer Berlin Heidelberg, 2012.

Hafiza, S. and Neelormi, S.: Climate resilient and empowering livelihoods for women, UN Women: Dhaka, Bangladesh, 1-61, 2015

Hagen-Zanker, J. and Mallet, R.: How to do a rigorous, evidencefocused literature review in international development: A guidance note, Overseas Development Institute, London, 2013.

Haque, U., Hashizume, M., Kolivras, K. N., Overgaard, H. J., Das, B., and Yamamoto, T.: Reduced death rates from cyclones in Bangladesh: What more needs to be done?, B. World Health Organ., 90, 150-156, 2012.
Huq, S., Ali, S. I., and Rahman, A. A.: Sea-level rise and Bangladesh: a preliminary analysis, J. Coast. Res., Special Issue No. 14, 44-53, 1995.

IRIN Cyclone shelters - for livestock too, available at: http://www. irinnews.org/feature/2012/10/16 (last access: 21 July 2017), 2012.

Jia, Z.: Cyclone shelters and cyclone resilient design in coastal areas of Bangladesh, Thesis submitted to the Department of Urban Studies and Planning in partial fulfilment of the requirements for the degree of Master in City Planning at the Massachusetts Institute Of Technology, September 2012.

Johnson, M. A.: Disaster preparedness education in schools: Recommendations for New Zealand and the United States, ISBN 978-1-877502-27-9, 2011.

Jonkman, B.: Loss of life assessment in flood risk assessment Theory and applications, Dissertation submitted for the degree of Doctor of Philosophy, June 2007, Technical University of Delft, The Netherlands, 2007.

Kates, R. W., Colten, C. E., Laska, S., and Leatherman, S. P.: Reconstruction of New Orleans after Hurricane Katrina: A research perspective, P. Natl. Acad. Sci. USA, 103, 14653-14660, https://doi.org/10.1073/pnas.0605726103, 2006.

Kates, R. W., Travis, W. R., and Wilbanks, T. J.: Transformational adaptation when incremental adaptations to climate change are insufficient, P. Natl. Acad. Sci. USA, 109, 71567161, https://doi.org/10.1073/pnas.1115521109, 2012.

Keyser, J. and Smith, W.: Disaster relief management in Cuba: Why Cuba's disaster relief model is worth careful study, International Policy Report, 1-7, May 2009.

Kron, W.: Coasts: the high-risk areas of the world, Nat. Hazards, 66, 1363-1382, 2013.

Lagmay, A. M. F., Agaton, R. P., Bahala, M. A. C., Briones, J. B. L. T., Cabacaba, K. M. C., Caro, C. V. C., Dasallas, L. L., Gonzalo, L. A. L., Ladiero, C. N., Lapidez, J. P., and Mungcal, M. T. F.: Devastating storm surges of Typhoon Haiyan, Int. J. Disast. Risk Re., 11, 1-12, 2015.

Lavelle, K. F: Hurricane Katrina: The race and class debate, monthly review, available at: http://monthlyreview.org/2006/07/ 01/hurricane-katrina-the-race-and-class-debate/ (last access: 21 July 2017), 2006.

Lezcano, J. C.: Aspectos esenciales sobre la mitigacion de los desastres naturales en Cuba, 399-406, in Cuba in Transition, Proceeding, Fifth Annual Meeting of the Society for the Study of the Cuban Economy, Vol. 5. Washington, D.C., Association for the Study of the Cuban Economy, 1995.

Lonsdale, K., Pringle, P., and Turner, B.: Transformative adaptation: what it is, why it matters and what is needed. UK Climate Impacts Programme, University of Oxford, Oxford, UK, 2015.

Lumbroso, D. M., Simm, J. D., Davison, M., White, K. D., and Durden, S.: Use of agent-based modelling to validate hurricane evacuation planning, Coastal Structures and Solutions to Coastal Disasters joint conference, Boston, Massachusetts, USA, 9-11 September 2015.

Macardle, A. L.: Storm surges, disaster planning, and vulnerable populations at the urban periphery: Imagining a resilient New York after superstorm Sandy, Idaho Law Review, 50, 19-23, 2014.

Majumder, S.: The economics of early response and resilience: Bangladesh country study, available at: https: 
//www.gov.uk/government/uploads/system/uploads/attachment_ data/file/228494/TEERR_Bangladesh_Background_Report.pdf (last access: 21 July 2017), 2013.

Mathbor, G. M.: Enhancement of community preparedness for natural disasters: The role of social work in building social capital for sustainable disaster relief and management, Int. Soc. Work, 50, 357-369, 2007.

Martinich, J., Neumann, J., Ludwig, L., and Jantarasami, L.: Risks of sea level rise to disadvantaged communities in the United States, Mitig. Adapt. Strat. Gl., 18, 169-185, 2013.

Mesa, G.: The Cuban health sector \& disaster mitigation, MEDICC review, 10, 5-8, 2008.

Miyan, M. A.: Cyclone disaster mitigation in Bangladesh, South Asian Disaster Management Center (SADMC), available at: http://www.fao.org/forestry/ 11285-03611be0ad43d80eefb3de4a8ee2e1fd0.pdf, (last access: 21 July 2017), 2005.

Ministry of Environment and Forests: Climate change strategy and action plan 2009, Ministry of Environment and Forests, Government of the People's Republic of Bangladesh, Dhaka, Bangladesh, 2009.

Moore, M., Trujillo, H. R., Stearns, B. K., Basurto-Davila, R., and Evans, B. K.: Models of relief: Learning from exemplary practices in international disaster management, WR-514, August 2007, Prepared for RAND Center for Domestic and International Health Security, 2007.

Moore, M., Trujillo, H. R., Stearns, B. K., Basurto-Davila, R., and Evans, B. K.: Learning from exemplary practices in international disaster management: A fresh avenue to Inform U.S. policy?, J. Homel. Secur. Emerg., 6, https://doi.org/10.2202/15477355.1515, 2009.

Morrow, B. H.: Identifying and mapping community vulnerability, Disasters, 23, 1-18, 1999.

Morrow, B. H. and Lazo, J. K.: Survey of coastal emergency managers perspectives on NWS storm surge information: Hurricane forecast improvement program/storm surge roadmap, NCAR Tech. Note NCAR/TN-495+STR, 84 pp., https://doi.org/10.5065/D6XG9P4M, 2013a.

Morrow, B. H. and Lazo, J. K.: Emergency managers on-line survey on extratropical and tropical cyclone forecast information: Hurricane forecast improvement program/storm surge roadmap, NCAR Tech. Note NCAR/TN-497+STR, 87 pp., https://doi.org/10.5065/D65X26X4, 2013b.

Morrow, B. H. and Lazo, J. K.: Broadcast media on-line survey on extratropical and tropical cyclone forecast information: NOAA storm surge roadmap and hurricane forecast improvement program, NCAR Tech. Note NCAR/TN-498+STR, 83 pp., https://doi.org/10.5065/D69P2ZM1, 2013c.

Morrow, B. H., Lazo, J. K, Rhome, J., and Feyen, J.: Improving storm surge risk communication: Stakeholder perspectives, Am. Meteor. Soc., 35-48, https://doi.org/10.1175/BAMS-D-1300197.1, 2014.

Muttarak, R. and Lutz, W.: Is education a key to reducing vulnerability to natural disasters and hence unavoidable climate change?, Ecol. Soc., 19, 42, 2014.

Naranjo Diaz, L.: Hurricane early warning in Cuba: An uncommon experience, available at: www.disasterdiplomacy.org/ NaranjoDiazMichelle.rtf (last access: 21 July 2017), 2003.
Newhouse, E.: More lessons from Cuba's hurricane preparedness and civil defense, Center for International Policy, Delegation report, December 2011, available at: http://reliefweb.int/sites/ reliefweb.int/files/resources/Full_doc_8.pdf (last access: 21 July 2017), 2011.

Norris, F., Stevens, S., Pfefferbaum, B., Wyche, K., and Pfefferbaum, R.: Community resilience as a metaphor, theory, set of capacities and strategy for disaster readiness, Am. J. Commun. Psychol., 41, 127-225, 2008.

Neumann, B., Vafeidis, A. T., Zimmermann, J., and Nicholls, R. J.: Future coastal population growth and exposure to sealevel rise and coastal flooding-a global assessment, PloS one, 10, p.e0118571, https://doi.org/10.1371/journal.pone.0118571, 2015.

Nicholls, R. J.: Storm surges in coastal areas, Natural disaster hotspots, case studies, The World Bank Hazard Management Unit, Disaster Risk Management Series, 79-108, 2006.

Ortiz, J. J.: Protecting children takes more will than resources: Jose Juan Ortiz, UNICEF representative in Cuba, Interview by Conner Gorry, MEDICC review, 12, 10-2, 2010.

Park, S. E., Marshall, N. A., Jakku, E., Dowd, A. M., Howden, S. M., Mendham, E., and Fleming, A.: Informing adaptation responses to climate change through theories of transformation, Global Environ. Chang., 22, 115-126, 2012.

Paul, B. K.: Why relatively fewer people died? The case of Bangladesh's Cyclone Sidr, Nat. Hazards, 50, 289-304, 2009.

Paul, B. K.: Human injuries caused by Bangladesh's cyclone Sidr: An empirical study, Nat. Hazards, 54, 483-495, 2010.

Paul, A. and Rahman, M. M.: Cyclone mitigation perspectives in the islands of Bangladesh: A case of Sandwip and Hatia Islands, Coast. Manage., 34, 199-215, 2006.

Pasquali, V.: The world's richest and poorest countries, Global Finance Magazine, November 2015, available at: https://www.gfmag.com/global-data/economic-data/ worlds-richest-and-poorest-countries, 2015.

Pawson, R. and Tilley, N.: Realistic evaluation, in: Encyclopaedia of Evaluation Newbury Park: Sage, edited by: Matthieson, S., 2004.

Pawson, R., Greenhalgh, T., Harvey, G., and Walshe, K.: Realist review - A new method of systematic review designed for complex policy interventions, Journal of Health Services Research and Policy 2005, 10, 21-34, 2005.

Pichler, A. and Striessnig, E.: Differential vulnerability to hurricanes in Cuba, Haiti, and the Dominican Republic: The contribution of education, Ecol. Soc., 18, 2013.

Porter, J. J., Dessai, S., and Tompkins, E. L.: What do we know about UK household adaptation to climate change? A systematic review, Clim. Change, 127, 371-379, 2014.

Putnam, R. D.: Bowling alone: America's declining social capital, J. Democr., 65-78, 1995.

Rahman, A. and Islam, R.: Bangladesh - adapting to cyclone storm surges: Shelters and schools in Climate of Coastal Cooperation, edited by: Edi Misdorp, R., Coastal \& Marine Union (EUCC), Leiden, The Netherlands, 69-71, 2011.

Reardon, S.: The widening academic achievement gap between the rich and the poor: New evidence and possible explanations in Whither opportunity?, edited by: Duncan, G. J. and Murnane, R. J., 2011.

Roy, C.: An informed system development approach to tropical cyclone track and intensity forecasting, Linköping Stud- 
ies in Science and Technology, Dissertations, No. 1734, available at: http://www.diva-portal.org/smash/get/diva2: 882030/FULLTEXT02.pdf (last access: 21 July 2017), 2016.

Roy, C. and Kovordanyi, R.: The current cyclone early warning system in Bangladesh: Providers' and receivers' views, 2015, Int. J. Disast. Risk Re., 12, 285-299, https://doi.org/10.1016/j.ijdrr.2015.02.004, 2015.

Roy, C.: An informed system development approach to tropical cyclone track and intensity forecasting, Linköping Studies in Science and Technology, Dissertations. No. 1734, available at: http://www.diva-portal.org/smash/get/diva2: 882030/FULLTEXT02.pdf (last access: 21 July 2017), 2016.

Rubeiera, J.: Hurricane early warnings and warnings: A Cuban experience, International seminar, Caribbean cluster on natural risks and risks from the sea, Martinique, 27-29 March 2012, 2012.

Schuett, J. and Silkwood, E.: Reducing risks, avoiding disaster: Managing hurricanes the Cuban way, International Policy Report, August 2008.

Schultz, M. T. and Smith, E. R.: Assessing the resilience of coastal systems: A probabilistic approach, J. Coast. Res., 32, 1032-1050, https://doi.org/10.2112/JCOASTRES-D15-00170.1, 2016.

Sims, H. and Vogelmann, K.: Popular mobilization and disaster management in Cuba, Public Admin. Develop., 22, 389-400, 2002.

Spanger-Siegfried, E., Fitzpatrick, M. and Dahl, K.: Encroaching tides: How sea level rise and tidal flooding threaten US east and gulf coast communities over the next 30 years, available at: http://www.ucsusa.org/sites/default/files/attach/2014/10/ encroaching-tides-full-report.pdf (last access: 21 July 2017), 2014.

Srinivasan, S., O'Fallon, L. R., and Dearry, A.: Creating healthy communities, healthy homes, healthy people: Initiating a research agenda on the built environment and public health, Am. J. Publ. Health, 93, 1446-1450, 2003.

Thompson, M.: Lessons in risk reduction from Cuba; Case study prepared for Enhancing Urban Safety and Security, Global Report on Human Settlements, 1-15, 2007.

Thompson, M. and Gaviria, I.: Cuba: Weathering the storm: Lessons in risk reduction from Cuba, Oxfam America,, available at: https://www.oxfamamerica.org/static/oa3/files/OA-Cuba_ Weathering_the_Storm-2004.pdf, (last access: 21 July 2017), 2004.

Thompson, H. E., Berrang-Ford, L., and Ford, J. D.: Climate change and food security in sub-Saharan Africa: A systematic literature review, Sustainability, 2, 2719-2733, 2010.

United Nations Development Programme (UNDP): A global report: Reducing disaster risk: A challenge for development available at: http://www.undp.org/content/ undp/en/home/librarypage/crisis-prevention-and-recovery/ reducing-disaster-risk--a-challenge-for-development.html, (last access: 21 July 2017), 2004.

United Nations International Strategy for Disaster Reduction (UNISDR): Towards a culture of prevention: Disaster risk reduction begins at school - Good practices and lessons learned, available at: http://www.unisdr.org/files/761_ education-good-practices.pdf (last access: 21 July 2017), 2007.
United Nations Development Programme (UNDP): A Cuban model for a resilient Caribbean, available at: http://www.undp.org/content/undp/en/home/presscenter/articles/ 2015/02/25/a-cuban-model-for-a-resilient-caribbean.html, (last access: 21 July 2017), 2015.

United States Army Corps of Engineers (USACE): Discussing the results of the Georgia Hurricane evacuation study options for public involvement and risk communication, 5 June 2014, available at: http://www.corpsriskanalysisgateway.us/lms/ docs/webinars/RiskWebinarBoostingLocalPrep/Draft_Report_ Outreach_Options_for_GAHES_6_5_2014.pdf (last access: 21 July 2017), 2014.

United States Army Corps of Engineers (USACE): North Atlantic coast comprehensive study: Resilient adaptation to increasing risk. Main report. US Army Corps of Engineers, available at: www.nad.usace.army.mil/Portals/40/docs/NACCS/ NACCS_main_report.pdf (last access: 21 July 2017), 2015.

Walker, B., Holling, C. S., Carpenter, S. R., and Kinzig, A.: Resilience, adaptability and transformability in social - ecological systems, Ecol. Soc., 9, p. 5, 2004.

Wallace, J. W., Poole, C., and Horney, J. A.: The association between actual and perceived flood risk and evacuation from Hurricane Irene, Beaufort County, North Carolina, J. Flood Risk Manage., 9, 125-135, 2016.

Weiss, D. J. and Weidman, J.: Disastrous spending: Federal disasterrelief expenditures rise amid more extreme weather, Center for American Progress, 2013.

Wisner, B.: SHINK and swim: Exploring the link between capital (Social, Human, Institutional, Natural), disaster, and disaster risk reduction, in: Background Paper for the UN Project on the Economics of Disaster Risk Reduction (EDRR) and the World Bank, 2009.

Wong, P. P., Losada, I. J., Gattuso, J.-P., Hinkel, J., Khattabi, A., McInnes, K. L., Saito, Y., and Sallenger, A.: Coastal systems and low-lying areas. in: Climate Change 2014: Impacts, Adaptation, and Vulnerability. Part A: Global and Sectoral Aspects, Contribution of Working Group II to the Fifth Assessment Report of the Intergovernmental Panel on Climate Change, 2014.

World Bank: International development association project appraisal document on a proposed credit in the amount of SDR253.7 million (USD 375 million equivalent) to the People's Republic of Bangladesh for a multipurpose disaster shelter project, 19 November 2014, available at: http://www-wds worldbank.org/external/default/WDSContentServer/WDSP/ IB/2014/11/26/000470435_20141126094946/Rendered/PDF/ PAD8070PAD0P14010Box385378B00OUO090.pdf (last access: 21 July 2017), 2014.

World Meteorological Organization (WMO): Country report of Bangladesh, available at: https://www.wmo.int/pages/prog/ www/tcp/documents/Bangladesh.doc, 2011

Zissimopoulos, J. and Karoly, L. A.: Employment and selfemployment in the wake of Hurricane Katrina, Demography, 47, 345-367, 2010. 